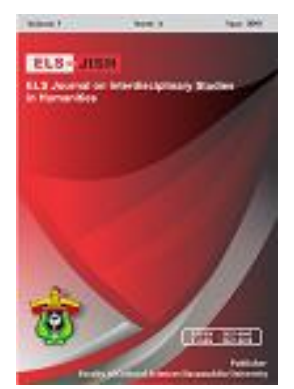

\title{
ELS-JISH
}

ELS Journal on Interdisciplinary Studies on Humanities

Volume 2 Issue 4, 2019

ISSN (print) : 2621-0843

ISSN (online) : 2621-0835

Homepage : http://journal.unhas.ac.id/index.php/jish

\section{Teacher's Beliefs and Practices in the Integration of Higher Order Thinking Skills in Teaching Reading}

\author{
Muhammad Ansori ${ }^{1}$, Joko Nurkamto ${ }^{2}$, Suparno ${ }^{3}$ \\ 1 muhammadansori1809@gmail.com
}

\begin{abstract}
Higher Order Thinking Skills (HOTS) is an essential skill for students to compete in this technological age. Hence, teachers need to hold strong beliefs about HOTS as it influences their classroom practices. Moreover, the study about HOTS in English language teaching has not been widely explored. This case study seeks to explore teacher's beliefs in the integration of HOTS in teaching reading and how the beliefs are reflected in classroom practices. Further, it also investigates the factor influencing the teacher's beliefs and practices. The participant was an experienced English teacher in a public senior high school. Data were collected using interviews, observation, and review of documents. Data then were analyzed using the Pattern Matching technique (Yin, 2018) and interactive model data analysis (Miles, Huberman, \& Saldaña, 2014). The results revealed that the teacher held strong beliefs about the integration of HOTS in teaching reading. These beliefs include belief about the conception of HOTS, the importance of HOTS, the role of the teacher, the strategies to promote HOTS, and the assessment of HOTS. In practice, the teacher did not fully reflect what she believes, especially about the assessment of HOTS. It also found that training, learning experience, teaching experience, institutional factor, student factor, and availability of learning support influenced teacher beliefs and practice in integrating HOTS in teaching reading. This study implies that there needs more teachers' professional development to support the successful integration of HOTS in English language teaching.
\end{abstract}

Keywords: Higher Order Thinking Skills; Belief and Practice; EFL; Teaching Reading

How to cite: Ansori, M., Nurkamto, J., \& Suparno (2019). Teacher's Beliefs and Practices in the Integration of Higher Order Thinking Skills in Teaching Reading. ELS Journal on Interdisciplinary Studies in Humanities, 2(4), 541-555

\section{Introduction}

Some studies have proven that higher-order thinking skills (HOTS) are an essential and relevant skill in today's challenging era (Brookhart, 2010; Coffman, 2013; Yen \& Halili, 2015) Those thinking skills are also crucial for people in the 21st century, both in the workplace and in making reasoned choices in daily lives (Coffman, 2013). Most of the teachers also agree that it is crucial to teach HOTS since it is relevant to global economic growth, the development of information and

\footnotetext{
${ }^{1,2,3}$ Universitas Sebelas Maret, Indonesia 
communication technology (ICT), a knowledge-based economy, and a fast-paced world (Yen \& Halili, 2015).

The Indonesian government has integrated HOTS into Curriculum 2013 (K13). Several reasons lie behind this integration. First, it is in line with the goal of the national education system that "... to develop students' potential to become a critical, creative, and independent citizen" (Sistem Pendidikan Nasional, 2003). Second, the government expects students to achieve various competencies, including critical thinking, creative and innovative, communication skills, collaboration, and confidence (Ariyana et al., 2018). The last, Indonesia's ranking in Programme for International Student Assessment (PISA) and Trends in the International Mathematics and Science Study (TIMSS) show unsatisfactory score in science, mathematics, and reading, although there has been a slight increase especially in science and mathematics (OECD, 2016). More than that, integrating HOTS in all school's subject is the government's effort to improve the quality of the learning process and learning outcomes (Ariyana et al., 2018).

As mentioned before, Indonesian students' ranking in PISA is still at a low level in reading (OECD, 2016). Integrating HOTS in reading means that students will not merely learn about linguistics knowledge, but also learn how to respond to the information critically, how to become creative thinkers, and reflect on their thinking skills (Li, 2016). Moreover, most of the formal tests use the written word as a stimulus for a test-taker response; Even oral interviews may require reading performance for specific tasks. That is the way reading becomes an essential skill for success in all educational contexts (Brown, 2003). In other words, integrating HOTS into reading skill means teaching students to analyze and evaluate the information in the text critically, and to create a new idea or concept from the text.

Teachers always play a vital role in integrating HOTS into their classroom practices. One of their roles is that "teachers must encourage and respect students to ask questions and express opinions" (Kementerian Pendidikan dan Kebudayaan Republik Indonesia, 2016). It indicates that one of their roles is as a facilitator. They have to direct and support students in the learning process. They should create a learning environment that develops students' intellectual and thinking skills development. Besides, they also play various vital roles such as a learner, facilitator, assessor, manager, and evaluator (Archana \& Usha Rani, 2017). Hence, it is crucial to explore their beliefs and practices of HOTS because what teachers do reflect what they know and believe and serve as the fundamental framework that guides their classroom practice (Richards \& Lockhart, 1996).

\section{Review of Related Literature}

\subsection{The Concept of Higher Order Thinking Skills}

Higher-order thinking skill (HOTS) is a complex mental process that requires nuanced judgment and interpretation, analysis of complex situations according to multiple criteria (Resnick, 1987). HOTS occurs when someone gains new information and stores it in memory and associates, rearranges, and expands that information to find possible answers in confusing situations (Lewis \& Smith, 1993). HOTS also challenge students to interpret, analyze, or manipulate information. They could not answer a question or solve a problem through the routine application of previously learned knowledge; they have to interpret, analyze, and manipulate the information 
(Newmann, 1990). Whereas, for many educators, HOTS is associated as the "top end" of Bloom's taxonomy of learning: Analyze, Evaluate, and Create, or, in the older language: Analysis, Synthesis, and Evaluation (Anderson \& Krathwohl, 2001; Brookhart, 2010).

Bloom's taxonomy (Bloom, 1956) educational objective is "a framework for classifying statements of what we expect or intend students to learn as a result of instruction" (Krathwohl, 2002). This taxonomy divides the thinking skills or cognitive aspects into six levels, namely Knowledge, Comprehension, Application, Analysis, Synthesis, and Evaluation. Then, Anderson and Krathwohl (Anderson \& Krathwohl, 2001) revised these cognitive aspects to Remembering, Understanding, Applying, Analyzing, Evaluating, and Creating. Later, the Ministry of Education and Culture of Indonesia sets them to measure students' knowledge aspects. It is outlined in the regulation of the Ministry of Education and Culture number 22 of 2016 that states that "knowledge is obtained through activities "remembering (C1), understanding (C2), applying (C3), analyzing (C4), evaluating (C5), and creating (C6)" (p. 3) (Kementerian Pendidikan dan Kebudayaan Republik Indonesia, 2016).

\subsection{The Concept of Teacher Belief}

Richardson (1996) defines belief as mentally-held understandings, premises, or propositions about the world that are felt to be true. Belief consists of four essential components; cognitive, affective, evaluative, and behavioral components (Borg, 2011; Nespor, 1987; Rokeach, 1968). The cognitive component involves knowledge. The cognitive component reflects knowledge when the belief functions as a proposition or assumption about a person, an object, or an event. The next component is the affective component. It includes the emotion or feeling. Another component is the evaluative component, which is essential because it serves to compare the existing belief with the new one that leads to the acceptance or rejection of the new belief. It also serves as an essential regulator to predict how much energy teachers will use in classroom practice. The last is behavioral components. It is activated when action is required. It is also the manifestation of the cognitive and affective component in the form of practice.

Additionally, teachers' belief systems can be identified on the goals, values, and beliefs that teachers have about the content and teaching process, and their understanding of the systems in which they work and their roles within it (Richards \& Lockhart, 1996). The beliefs held by teachers will lead to different interpretations and sometimes end up with the mismatch in their classroom practice. As theories mentioned, teachers' beliefs are closely related to their classroom practice (Borg, 2003)(Pajares, 1992).

Previously, there has been a growing body of research conducted to explore teachers' beliefs about thinking skills. Aziz et al. (2017) researched to examine ESL teachers' beliefs and practices of HOTS in Malaysia. The results revealed that teachers were aware of their responsibility to integrate HOTS in their teaching. They believed that they could use some resources for the effective learning of HOTS in their classrooms. For the practice, the results showed that they frequently used a low level of questioning and low-level thinking verbs in the classroom. By contrast, the results of the research conducted by Hasni, Ramli, and Rafek (2018) indicated that Malaysian lecturers know that thinking skills are essential and understand the 
concept of thinking skills. Moreover, there was a match between their beliefs about thinking skills and their classroom practice.

Li (2016) conducted another research about teachers' cognition and thinking skills in China. She found that EFL teachers in China found it challenging to define thinking skills and had a lack of understanding of the concept of thinking skills. Besides, although they showed a positive attitude towards the integration of thinking skills in the language classroom, they did not believe that the language classroom should promote those skills. Li's research also implied that EFL teachers believe that it was possible to teach thinking skills, primarily through reading, science, and mathematics. In contrast to Li's findings, the research conducted by Tuzlukova, Al Busaidi, and Burns (2017) in Oman showed that teachers understood the concept of thinking skills. They also believed that thinking skills were necessary and beneficial, so language teaching should incorporate them.

To conclude, based on the background of the problems and shortcomings of the research about the teachers' beliefs and practices of HOTS in English language teaching, this research is conducted to explore an English teacher's' beliefs and practices in the integration of HOTS in teaching reading. Besides, it also investigates the factors influencing teacher's beliefs and practices.

\section{Method}

To explore the research problems, the researchers applied a case study research design. A case study is appropriate with the research since the aims of the research are to explore human behavior in a real-world setting in the form of teacher beliefs about HOTS and its classroom practices through a detailed and holistic description. A case study is an empirical investigation that investigates a contemporary phenomenon in its real-life context, especially when the boundaries between phenomenon and context are not clear and in which multiple sources of evidence are used (Yin, 2003).

The participant in this research was selected purposively. The participant was Teacher Ana (Pseudonym). She is a 37 years old female. She got her bachelor's degree in English literature from a state university in Malang, East Java. She has been teaching English for more than 12 years in a public senior high school in Bojonegoro, East Java. She has participated in the training related to HOTS-based learning. Also, she is a certified professional teacher. Thus, the researchers decided to select her as the participant because she already met the criteria needed. The decision to choose one participant was also to get more detailed and in-depth information.

The data were collected through a semi-structured interview, classroom observations, and a review of documents. The interview data were audio-taped with the permission of the participant. Meanwhile, teaching and learning activities are recorded using a video recorder with the participant's agreement. Field notes were also used to record ongoing activities during the observation process. Besides, reviewing documents here includes the teacher's syllabus, lesson plans, the interview' transcripts, and field notes. To address the validity of the research findings, the researcher used triangulation (data sources and methods) and member checking. 
The collected data then analyzed using the pattern-matching technique (Yin, 2018). This technique compares an empirically based pattern with a predicted pattern made before data collection (Yin, 2018). This technique is also intended to enhance the rigor of the research. If the empirically-found patterns match the predicted ones, the findings can strengthen the internal validity of the study. In contrast, if the predicted and experienced patterns do not match, the researcher must examine alternative explanations for the findings. The first step in data analysis using this technique is that each of the collected data first analyzed independently. The interview transcript, observation field notes, and documents are analyzed inductively using interactive model data analysis (Miles et al., 2014) consisting of data condensation, data display, and drawing conclusion/verification. The next step is to synthesize the understanding gained from these multiple methods using pattern matching techniques (Yin, 2018) to develop research findings.

\title{
4. Findings
}

The findings are categorized into several themes: beliefs about the conception of HOTS, the importance of HOTS, the role of teacher, teaching strategies to promote HOTS, and beliefs about the assessment of HOTS. Each of theme explains as follows:

\subsection{Teacher Beliefs about HOTS in Teaching Reading}

\subsubsection{Belief about the Conception HOTS}

The first finding is about the conception of HOTS. Teacher Ana believed that HOTS is a representation of the level of thinking skills from the lower level to a higher level. For her, these levels of thinking skills then divided into $\mathrm{C} 1$ to $\mathrm{C} 6 . \mathrm{C} 1$ is Knowing, C2 is Understanding, C3 is Implementing or Applying, C4 is Analyzing, C5 is Evaluating and Assessing, and C6 is Creating. More explanation is shown in the interview transcript below.

\begin{abstract}
HOTS is higher-order thinking skills. So, it is higher thinking skills. It represents the level of thinking from the lower to the higher level. In the definition of HOTS, there are terms C1, C2, C3, C4, C5, up to C6. Where C1 is the lowest level, only knowing, then C2 is understanding, the third is implementing or applying, the fourth is analyzing, then C5 is evaluating, assessing, and C6 is creating (1.01/TA).
\end{abstract}

The next question is about the components of HOTS in Bloom's Taxonomy. She believed that the components of HOTS in Bloom's taxonomy are in levels two and three, which are analyzing, evaluating, and creating. See the result of the interview below:

There are six C. C1 to C6 simplified into three levels. The level one is C1, C2, C3, namely Knowing, Understanding, and Applying. Level one is still LOTS. While those who are considered HOTS are L2 and L3. L2 is Analyzing called $\mathrm{C} 4$, and the highest in the three concepts are $\mathrm{L} 3$, where $\mathrm{L} 3$ consists of C5 and C6, which are Evaluating and Creating (I.02/TA).

The researchers then asked the teacher to define each component of the HOTS. Teacher Ana explained that analyzing is when students are not only able to apply and understand but also to infer the information. Meanwhile, evaluating is the ability to judge a discourse (a text or an opinion). The last, creating is a process of 
compiling and presenting an idea. The interview transcript below shows in detail her beliefs about the definition of each component of HOTS.

\begin{abstract}
Analyzing means students are able not only to apply and understand, but they are also able to infer certain information that they hear, observe, or read. Whereas Evaluating is a skill to judge a discourse, whether it is a text or opinion of others. It can be done by comparing that is also included in Evaluation. Whereas Creating, if in English teaching, means from a concept they compile or present an idea, it is already involved in Creating because they formulate information into other forms of their creation (I.02/TA).
\end{abstract}

\title{
4.1.2 Belief about the Importance of HOTS
}

Teacher Ana believed that HOTS is essential for students, especially in reading. It is one of the crucial skills for students. For her, students should master reading skills very well. Integrating HOTS in reading is essential. It is because lately, the existing tests such as UNBK, SBMPTN, and TOEFL test used HOTS-based questions. So, students have to be able not only to read but also able to analyze the text and create their own. Take a look at the interview transcript below.

\begin{abstract}
For students, HOTS is very important. When talking about the concept of English learning, reading is one of the skills that are as important as other skills. It is also beneficial in their real-life; it is clear that students are required to master reading skills very well. The most obvious thing is the existence of tests such as the UNBK test, the presence of the SBMPTN test, even the TOEFL test, or texts about advertising, pamphlets, job vacancies. Our students have to master them, not only merely read, but also have to be able to analyze, and in the end, they can create their work (I.01/TA).
\end{abstract}

Teacher Ana further added that as the young generation of the nation, students must have critical thinking skills. They have to be critical about what happened in their society. So, the teaching-learning process should accustom them to think critically and even create something creatively. Her belief is reflected below:

It is essential because, as the young generation of the nation, they must automatically be critical of what is happening. How can they be critical if they are not accustomed to judging something, then conveying or even creating something of their version (I.02/TA).

\subsubsection{Belief about the Role of Teacher}

The next theme is about what teacher beliefs about the role of the teacher in integrating HOTS. Teacher Ana believed that her role is to stimulate students with questions that require multiple answers. So, students can develop their analyzing skills and express their ideas and opinion. Her belief is stated below.

The teacher's role in the integration of HOTS certainly stimulates students with questions whose answers can vary. So, students can express their ideas, opinions, then analyze them, and their skills can develop freely (I.01/TA).

\subsubsection{Belief about Strategies to Promote HOTS}

Another theme deals with the teacher's beliefs about strategies to integrate HOTS. Teacher Ana believed that teaching strategy is an effort made by teachers so that the teaching and learning activities achieved the planned target. The effort can be in the form of using certain media, games and doing fun activities. 
Teaching strategy is an effort that can be taken as a step, so that teaching and learning activities run according to the targets that have been designed". By utilizing amusing media, games, and exciting activities (I.01/TA).

Dealing with teaching strategy to promote HOTS, she believed that group discussions, question and answer, and game are some of the teaching strategies to promote HOTS in teaching reading. She explains that:

\begin{abstract}
In reading, I usually give a text. Then with the text, I ask students to read using not unclassical reading techniques such as reading in a given time limit because with that technique, students must feel bored, so I ask them to create groups, in groups, then later, I will give them time to turn over. So, they must first present the contents of the text they read, and then there is a classical question and answer session. It is usually the initial activity in building students' concepts. Only when they understand what the text is about, I will provide another text. It can be in the form of a game. In this way, students, whether they want it or not, will try to understand the text and analyze it and I compete the game between groups so that they can compete with each group, there are points in the games (I.01/TA).
\end{abstract}

The result of document analysis stated that she used Cooperative learning as the learning model. She also used question-answer, the discussion, and playing game strategies.

\title{
4.1.5 Belief about the Assessment of HOTS
}

Teacher Ana believed that learning assessment is a series of assessments of the teaching and learning process used to assess students' spiritual and social attitudes, knowledge, and psychomotor aspects.

Learning assessment is a series of evaluation of the teaching and learning process (KBM) that assesses students, where aspects assessed include; spiritual and social attitudes, knowledge, and psychomotor (I.01/TA).

Meanwhile, in term of HOTS' assessment, she believed that quiz, presentation, daily test, and short essay are some assessment can be used to assess HOTS. Moreover, the most frequently assessment used are quizzes and regular tests. She expresses her beliefs in the statements below.

It could be a quiz, then a presentation, in addition to the quiz, of course, a daily test, then a short essay, ... the short essay's evaluation is to assess the extent of their analytical skills, usually so. The most frequently used are quizzes and daily tests (I.01/TA).

The result of document analysis revealed that she used written tests in the form of group assignments to assess students' knowledge aspects. The written test was a reading passage followed by six open-ended questions. She also provided scoring guidance and rubric.

\subsection{The Integration of HOTS in Teaching Reading}

In the first observation, Teacher Ana explained in detail about the learning objectives to students at the beginning of the lesson. The learning objectives at that meeting were to discuss the social functions, generic structures of the news text, what students could get after reading the text, how they can understand, conclude, and be aware of the importance of news items text for their life. In the second observation, she also explained the learning objectives for the meeting. She 
explained that the learning objective was to discuss news items texts. Besides, the activities that students would do were playing games related to the topic.

The roles of the teacher revealed during observations were the role of the teacher as a facilitator that creating a classroom environment that stimulates students to think, asking questions that stimulate the student to think at a higher level, structuring activities that encourage students thinking through group discussion and dialogues. The other role was as an assessor. She assessed students' knowledge by giving feedback.

Teacher Ana also applied some teaching strategies to promote HOTS in teaching reading. Those are scaffolding, questioning, game, small group discussion, and feedback. Regarding with scaffolding strategy, she asked students closed and open-ended questions about their experience related to the topic. Then, she asked the students to predict the topic of discussion. Having done it, she mentioned the learning objective of the meeting. She later asked students about the importance of reading news and explained about learning objectives. Besides, she played short videos about news to stimulate and engage students in the topic. In applying the questioning strategy, she often used questioning strategy at the beginning until closing activity. She frequently asked some questions to check students' understanding and knowledge at the beginning until the end of the activity. At the beginning of the activity, she also asked students questions about the news played in the videos. She asked about what the information students got from the videos, and so on. Meanwhile, in the main activity, she also asked questions to hear other students' opinions relating to the topic. In the post-activity, she often asked students the questions to conclude the learning topic.

Another strategy was the game. Teacher Ana used games both in the first and second meetings. The game was concerning the topic, which is about news item texts. The games in the first meeting were intended to arrange the jumbled paragraphs of news item text and to read and discuss the detail and general information in the text. In the second observation, the games aimed to challenge students to answers some questions about news item texts. The questions were taken both from the textbook and authentic material. She gave scores for those who could complete or answer the questions correctly. The next strategy she used was a small group discussion. Teacher Ana divided students into several groups; one group usually consisting of three to four students. After dividing groups, she gave instructions to each group. Teacher Ana then guided and controlled the group discussion. Having a discussion completed, she asked students to answer questions. One or more representatives of the group gave answers to the questions. Then, she often asked for another opinion from students toward the answers. She later gave some feedback. In the end, she gave scores. The last strategy revealed was feedback. Teacher Ana gave feedbacks during game activities. She gave the compliment to the group of students who could answer questions correctly. It happened both in the first and second observations. Moreover, at the end of the lesson, she asked all students to give applause for themselves as they have actively participated in the learning process.

Dealing with the assessment she used during classroom activities, Teacher Ana gave the scores for each game. These scores included in the cognitive and affective assessment. Besides, she also provided students with oral corrective feedback. It 
occurred when students could not give the correct answers. She also corrected the students' pronunciation. Meanwhile, the news item text from the Jakarta Post and textbooks are used during the main activities. The exercises were in the form of open-ended questions.

\subsection{The Factors Influencing Teacher Beliefs and Practices in the Integration of HOTS in Teaching Reading}

Some factors influence teacher beliefs and practices in the integration of HOTS in teaching reading. Those factors are training, learning experience, teaching experience, institutional factor, student factor, and availability of learning support.

\subsubsection{Training}

Teacher Ana believed that the training influenced her belief in the integration of HOTS. She stated that she got the initial concept of HOTS from the training she attended. Although the training did not thoroughly discuss specific skills, it did provide a general understanding of HOTS so that it influenced her beliefs.

\subsubsection{Learning Experience}

Learning experience also influenced the teacher's belief in integrating HOTS. According to Teacher Ana, since in a college, she had been accustomed to reading, analyzing, and presenting. These shaped her belief so that she transmitted it to students during classroom practice so that they would also have the same skill as her.

\subsubsection{Teaching Experience}

The next factor was the teaching experience. Teacher Ana had more than 12 years of teaching experience. This experience has influenced her beliefs in integrating HOTS in teaching reading. She believed that her teaching experience made her understand that every student and each class had their characters. They are different. Of course, she could not give the same treatment to all students and all classes.

\subsubsection{Institutional Factor}

The institutional factor was another factor that influenced the teacher's beliefs and practices to integrate HOTS into teaching reading. From the interview, the researchers concluded that institutional factors where she worked influenced the teacher's beliefs. Her school already required the integration of HOTS into all subjects. Besides, she had the responsibility to succeed in the implementation of HOTS in the learning process since she was a teacher in a public school.

\subsubsection{Students Factor}

The result of the interview confirmed that the factors of students' needs contribute to shaping teacher's belief in the integration of HOTS in teaching reading. Teacher Ana believed that the needs of students in this technological era are different. These needs include the need to face global challenges. Another need is to face a national exam that has implemented several HOTS-based questions. 


\subsubsection{Availability of Learning Support}

The last factor is the availability of learning support. Teacher Ana believed that students currently lived in the digital era in which the availability of learning support was easy. Also, the availability of adequate facilities in school helped support students' learning. These affected her belief in the integration of HOTS in teaching reading.

\section{Discussion}

The findings revealed that the teacher holds some belief regarding the conception of HOTS, including the definition of HOTS and the component of HOTS in Bloom's Taxonomy. All the conceptions teacher hold is coherent with relevant theories and a previous study (Anderson \& Krathwohl, 2001; Bloom, 1956; Resnick, 1987). There is only a misunderstanding about the way the teacher defines analyzing skills. According to Anderson and Krathwohl (2001), analyzing is the ability to break down a problem or question into small parts and determine the interrelationship between those parts. Although there is a little misconception in defining the concept of analyzing, the teacher still believed that the integration of HOTS is important for students, especially in reading. These beliefs about the conception and the importance of HOTS were reflected in classroom practice. By holding beliefs about the concept and importance of HOTS, in practice, the teacher not only stimulated students with lower-order thinking skill (LOTS) questions, but also encourage them to be able to answer HOTS questions which include analyzing, evaluating, and creating.

What the teacher belief about her role in integrating HOTS is also reflected in her classroom practices. Teacher Ana believed that her role in integrating HOTS is to stimulate students with questions that require multiple answers. Resnick (1987) mentioned that students' HOT skills would develop if the teacher challenges them with problems or questions whose solutions or answers vary and involve complex thinking processes. The teacher's statement also implied the role of a facilitator. It means that they have to direct and support students in the learning process (Archana \& Usha Rani, 2017). In classroom practices, the teacher support students by stimulating them with some questions at the beginning until the closing activity. The questions in the initial activity lead students to build the concept of a topic. Meanwhile, the questions in the main activity functioned for checking students' understanding, asking their opinion about the problem or topic, and some questions to enhance their HOT skills. The questions in the closing activity are mostly to encourage students to conclude the discussion.

Integrating HOTS into classroom practices needs some specific strategies (Ariyana et al., 2018; King, Goodson, \& Rohani, 2011). At the same time. It also indicated that teachers should be able to apply some specific strategies so that students' HOT skills can be enhanced effectively. Teacher Ana also holds some beliefs about teaching strategies to enhance students' HOT skills. For her, a strategy is a set of an effort made by teachers so that the teaching and learning activities achieved the planned target. Besides, she believed that group discussions, question and answer, and game are some strategies to promote HOTS in teaching reading. A strategy is the patterns of acts that serve to achieve certain outcomes. In the teaching and learning process, the strategy defined as instructional strategies. It is the means to achieve learning objectives (Gill \& Kusum, 2017). Some theories 
confirm the strategies stated by teachers. King et al. (2011) explained that team or group activities facilitate knowledge construction through social interaction. This strategy is also under the principle of Socio-cultural learning theory that social interaction influenced individual cognitive development (Vygotsky, 1934). Questioning strategy is another strategy to enhance students' higher-order thinking. This strategy can be matched with Bloom's taxonomy as a measurement to use when asking questions to help purposively plan for HOT (Conklin, 2012). Moreover, the game is also another strategy to promote HOT. The game to promote HOTS should require students to evaluate, create, or analyze (Anderson \& Krathwohl, 2001), and it must make students think deeply rather than just looking for facts to answer questions (Conklin, 2012).

Teacher's beliefs about strategies to promote HOTS are reflected in classroom practice. It showed that the teachers gave support to students by applying those strategies. She used the questioning strategy from the beginning of the closing activities. She also applied a small group discussion that consists of three to four students to facilitate students to discuss the materials. Moreover, she used some games activities to deliver the material during the main activities. The games challenge students to compete since the teacher gave them the points. More than that, the games challenge them to use their decision-making strategy to win the games. Besides, the games related to news items text so that teachers also used some HOTS questions in it.

Another belief is about the assessment of HOTS. The teacher believed that assessment is a series of assessments of the teaching and learning process used to assess students' spiritual and social attitudes, knowledge, and psychomotor aspects. In this case, the teacher believed that quiz, presentation, daily test, and short essay are some assessment can be used to assess HOTS. Theoretically, assessment is an ongoing process that includes a broader domain. Every time a student responds to a question, make a comment, or try new words, the teacher unconsciously assesses student performance.

Moreover, it can be informal, formal, formative, and summative assessment (Brown, 2003). One of the forms of assessment is using Bloom's Taxonomy (Bloom, 1956) that includes three cognitive domains, namely, cognitive, affective, and psychomotor domains. In assessing the cognitive domain that relates to HOTS, Brookhart (2010) explained that the assessment of HOTS could be through formative, summative, and performance assessment. Quiz, daily tests, and short essays included in the summative assessment (Brookhart, 2010). Meanwhile, the presentation included in performance assessment (Brookhart, 2010; Brown, 2003). The teacher's beliefs about the assessment of HOTS are basically in line with existing theories. However, the teacher did not fully reflect these beliefs in classroom practice. Teacher Ana provided students with oral corrective feedback to assess their performance. It happened when students could not give the correct answers. She also corrected the students' pronunciation. Meanwhile, the type of question items used both for group discussions and for written tests was in the form of WH questions or open-ended questions. Thus, inconsistencies arise between what is believed and practiced.

In the previous paragraph, it stated that the teacher holds complex beliefs about the integration of HOTS in teaching reading. Such beliefs shaped a strong basis for 
classroom practice. It also confirms the theories that beliefs held by teachers affect their behavior in the classroom (Borg, 2003; Farrell \& Bennis, 2013; Pajares, 1992). However, there is one belief that was not reflected in classroom practice. Indeed, the beliefs held by teachers are not always reflected in classroom practice. The results of this research supported the previous research conducted by Aziz et al. (2017) that found that although ESL teachers in Malaysia were aware of their responsibility to integrate HOTS in their teaching. They also believed that they could use some resources for the effective learning of HOTS in their classrooms. However, they were uncertain about how to plan, implement, and assess HOTS in the classroom. For the practice of HOTS in the classroom, the results showed that ESL teachers frequently used a low level of questioning and low-level thinking verbs in the classroom. In line with this, another study about teacher belief and practice conducted by Phipps and Borg (2009) revealed that the relationship between teacher's beliefs and practices is not always consistent. Hence, teacher classroom practice did not always reflect the teacher's stated beliefs (Borg, 2003).

Several factors influence teacher beliefs and practices. They are schooling, professional coursework, contextual factors, and classroom practice (Borg, 2003). In this research, it revealed that teacher's beliefs and practices are influenced by training, learning experience, teaching experience, institutional factor, student factor, and availability of learning support. All these factors shaped the teacher's beliefs and influenced classroom practices. The last three factors mentioned are contextual factors. They have powerful influences on teachers' beliefs and affect their classroom practice (Fang, 1996). They can be called external factors that can influence practice by modifying belief so that it may result in incongruence between belief and practice (Borg, 2003).

\section{Conclusion}

This research aims to explore teacher beliefs and practices in the integration of HOTS in teaching reading and to investigate the factors influencing teacher beliefs and practices. It revealed that the teacher held strong beliefs about the integration of HOTS in teaching reading. These beliefs include belief about the conception of HOTS, the importance of HOTS, the role of teachers, the strategies to promote HOTS, and the assessment of HOTS. In practice, the teacher did not fully reflect what she believes, especially about the assessment of HOTS. Some factors influence the beliefs held by the teacher. It found that training, learning experience, teaching experience, institutional factor, student factor, and availability of learning support influenced teacher beliefs and practice in integrating HOTS in teaching reading.

The results of this research illustrate that teachers need more professional development to support the successful integration of HOTS in English language teaching. The government needs to provide specific training for each subject so that teachers get a clear picture of how to integrate HOTS into classroom practices. The results of this case study provided an in-depth look at how the integration of HOTS in the English language teaching context. However, the results certainly cannot be generalized. Further researchers may research the broader context. Moreover, the researchers hope there will be further research related to HOTS in the ELT context since the research on this issue is still in infant stages and needed more exploration. 


\section{References}

Anderson, L. W., \& Krathwohl, D. R. (2001). A Taxonomy for Learning, Teaching, and Assessing: A revision of Bloom's taxonomy of educational objectives (Abridged E; L. W. Anderson, D. R. Krathwohl, P. W. Airasian, K. A. Cruikshank, R. E. Mayer, P. R. Pintrich, ... M. C. Wittrock, Eds.). New York: Longman, Inc.

Archana, S., \& Usha Rani, K. (2017). Role of A Teacher in English Language Teaching (ELT). International Journal of Educational Science and Research (IJESR), 7(February), 1-4.

Ariyana, Y., Pudjiastuti, A., Bestary, R., \& Zamroni. (2018). Buku Pegangan Pembelajaran Berorientasi Pada Keterampilan Berpikir Tingkat Tinggi (Sajidan \& R. Mohandas, Eds.). Jakarta: Direktorat Jenderal Guru dan Tenaga Kependidikan. Kementerian Pendidikan dan Kebudayaan.

Aziz, A. A., Ismail, F., Ibrahim, N. M., \& Samat, N. A. (2017). Investigating the Implementation of Higher Order Thinking Skills in Malaysian Classrooms: Insights from L2 Teaching Practices. Sains Humanika, 9(4-2), 65-73.

Bloom, B. S. (1956). Taxonomy of Education Objectives: The Classification of Educational Goals. Canada: David McKay Company, Inc.

Borg, S. (2003). Teacher cognition in language teaching: A review of research on what language teachers think, know, believe, and do. Language Teaching, 36(2), 81-109.

Borg, S. (2011). The impact of in-service teacher education on language teachers' beliefs. System, 39(3), 370-380.

Brookhart, S. M. (2010). How to Asess Higher-Order Thinking Skills in Your Classroom. In Assess Thinking Higher-Order Skills. Virginia, USA: ASCD.

Brown, H. D. (2003). Language Assessment: Principles and Classroom Practices. San Fransisco, California: Longman.

Coffman, D. M. (2013). Thinking about Thinking: An Exploration of Preservice Teachers' Views about Higher Order Thinking Skills. University of Kansas.

Conklin, W. (2012). Higher-Order Thinking Skills to Develop 21st Century Learners. Huntington Beach.: Shell Education.

Fang, Z. (1996). A review of research on teacher beliefs and practices. Educational Research, 38(1), 47-65.

Farrell, T. S. C., \& Bennis, K. (2013). Reflecting on ESL teacher beliefs and classroom practices: A case study. RELC Journal, 44(2), 163-176.

Gill, A. K., \& Kusum. (2017). Teaching Approaches, Methods, and Strategy. Scholarly Research Journal for Interdisciplinary Studies, 4/36. https://doi.org/10.21922/srjis.v4i36.10014

Hasni, N. A., Ramli, N. H. L., \& Rafek, M. (2018). Instructors' $€^{\mathrm{TM}}$ Beliefs on Critical Thinking and Their Classroom Practices: A Case Study. International Journal of Academic Research in Business and Social Sciences, 8(1), 506-516. https://doi.org/10.6007/ijarbss/v8-i1/3823 
Kementerian Pendidikan dan Kebudayaan Republik Indonesia. (2016). Peraturan Menteri Pendidikan dan Kebudayaan No. 22 Tahun 2016 Tentang Proses Standar Pendidikan Dasar dan Menengah. In Peraturan Menteri Pendidikan dan Kebudayaan. Jakarta, Indonesia.

King, F., Goodson, L., \& Rohani, F. (2011). Higher Order Thinking Skills: Definition, Teaching Strategies, Assessment. In Thinking. Tallahassee, FL: Florida State University: Center for Advancement of Learning and Assessment.

Krathwohl, D. R. (2002). A Revision of Bloom's Taxonomy: An Overview. Theory into Practice, 41(4), 212-219.

Lewis, A., \& Smith, D. (1993). Defining Higher Order Thinking. Theory Into Practice, 32(3), 131-137. https://doi.org/10.1080/00405849309543588

Li, L. (2016). Integrating thinking skills in foreign language learning: What can we learn from teachers' perspectives? Thinking Skills and Creativity, 22, 273-288. https://doi.org/10.1016/j.tsc.2016.09.008

Miles, M. B., Huberman, A. M., \& Saldaña, J. (2014). Qualitative Data Analysis: A Methods Sourcebook (Third Edit). USA: SAGE Publication Inc.

Nespor, J. (1987). The role of beliefs in the practice of teaching. Journal of Curriculum Studies, 19(4), 317-328. https://doi.org/10.1080/0022027870190403

Newmann, F. M. (1990). Higher-order thinking in teaching social studies: A rationale for the assessment of classroom thoughtfulness. Journal of Curriculum Studies, 22(1), 41-56. https://doi.org/10.1080/0022027900220103

OECD. (2016). Country note - results from PISA 2015: Indonesia. Oecd, 1-8. Retrieved from https://www.oecd.org/pisa/PISA-2015-Indonesia.pdf

Pajares, M. F. (1992). Teachers' Beliefs and Educational Research: Cleaning Up a Messy Construct. Review of Educational Research, 62(3), 307-332. https://doi.org/10.3102/00346543062003307

Phipps, S., \& Borg, S. (2009). Exploring tensions between teachers' grammar teaching beliefs and practices. System. https://doi.org/10.1016/j.system.2009.03.002

Resnick, L. B. (1987). Education and Learning to Think. In Education and Learning to Think. https://doi.org/10.17226/1032

Richards, J. C., \& Lockhart, C. (1996). Reflective Teaching in Second Language Classrooms. In J. C. Richards (Ed.), CAMBRIDGE LANGUAGE EDUCATION. New York: Cambridge University Press.

Richardson, V. (1996). The Role of Attitudes and Beliefs in Learning to Teach. Handbook of Research on Teacher Education, 102-119.

Rokeach, M. (1968). A Theory of Organization and Change Within Value-Attitude Systems. Journal of Social Issues, 24(1), 13-33. https://doi.org/10.1111/j.15404560.1968.tb01466.x

Sistem Pendidikan Nasional. (2003). Jakarta, Indonesia. 
Tuzlukova, V., Al Busaidi, S., \& Burns, S. L. (2017). Critical thinking in the language classroom: Teacher beliefs and methods. Pertanika Journal of Social Sciences and Humanities, 25(2), 615-633.

Vygotsky, L. (1934). Thought and language. In M. i rech (Ed.), Thought and Language. https://doi.org/10.4324/9781315524139

Yen, T. S., \& Halili, S. H. (2015). Effective Teaching of Higher-Order Thinking (HOT) in Education. The Online Journal of Distance Education and E-Learning, 3(2), 41-47. Retrieved from www.tojdel.net

Yin, R. K. (2003). Case Study Research: Design and Methods (Third Ed.). California: SAGE Publications.

Yin, R. K. (2018). Case Study Research and Applications: Design and Methods (Sixth Ed.). California: SAGE Publications. 